\title{
ANALISIS BONUS DEMOGRAFI SEBAGAI KESEMPATAN DALAM MENGOPTIMALKAN PEMBANGUNAN PERTANIAN DI SUMATERA BARAT
}

\author{
Demographic Bonis Analysis as Opportunity in Optimalizing \\ Agricultural Development In West Sumatera
}

\author{
Yusmarni \\ Dosen Program Studi Agribisnis Fakultas Pertanian Universitas Andalas. \\ yus_mrn@yahoo.com
}

\begin{abstract}
Demographic dividend is a dynamica in demographic that accurs due to the change of demographic structure based on age, where the number of productive population is higher than un-productive populatian. Indonesia has experiancing this conditian since 2015 untill 2035. Although west Sumatera is not fully experiancing demographic dividend, this conditions still offers an opportunity to improve welfare and promote a better economic development by improving and optimalizing the development of economic sector. Since agricultural sector is the biggest sector contributing to GDP and absorb labour in West Sumatera, the goverment should optimalize the develpment of this sector. Beside that, West Sumatera is a hinterland area $(L Q=1,750)$ that can provide agricultural commodity for other provinces. Assumingly that the requarement of a good quality of human resource is fulfilled, the ability to purchase of the productive population in Indonesia will increase and create more demand for good quality of agricultural commodities. Additionally, this condition is an opportunity of West Sumatera to develop sub-sector of agroindutry in order to create value added of agricultural commodity. The development of agroindustry not only will increase farmers income in rural area but also will reduce un-employment in West Sumatera.
\end{abstract}

Key word: demographic, development, agriculture

\section{PENDAHULUAN}

Sumatera Barat merupakan salah satu provinsi yang berada di sepanjang pesisir barat Pulau Sumatera bagian tengah yang berbatasan langsung dengan Samudera Indonesia. Provinsi yang didominasi Suku Minangkabau ini termasuk provinsi dengan jumlah penduduk yang sedikit jika dibandingkan provinsi lain di Pulau Sumatera dengan laju pertumbuhan penduduk yang cukup rendah. Selama periode tahun 1990 sampai 2000 laju pertumbuhan penduduk Sumatera barat tercatat 0,63 persen yang merupakan laju 
pertumbuhan penduduk terendah jika dibandingkan provinsi lain di Pulau Sumatera.

Dari sisi Demografi, Provinsi Sumatera Barat secara keseluruhan sebenarnya termasuk provinsi yang belum akan mendapatkan bonus demografi, karena angka dependency ratio nya yang masih tinggi. Pada tahun 2010 dependency ratio Sumatera Barat sebesar 57,7 dan pada tahun 2015 berkurang menjadi 55,6. Proyeksi yang dilakukan oleh Badan Pusat Statistik memprediksikan bahwa sampai pada tahun 2035 beban ketergantungan (dependency Ratio) Sumatera Barat masih diatas 50 yaitu sebesar 50,6. Selain itu meski angka beban ketergantungan Sumatera Barat masih lebih besar dari 50, tetapi trend dependency ratio sampai tahun 2035 menunjukkan angka beban ketergantungan yang terus menurun. Hal ini mengindikasikan bahwa Sumatera Barat sebenarnya berada diambang window of opportunity yang dapat dimaksimalkan. Berdasarkan proyeksi Badan Pusat Statistik, Sumatera Barat kemungkinan akan dapat menikmati bonus demografi pada periode 2030-2035. Hal ini menunjukkan bahwa jumlah orang yang harus ditanggung oleh penduduk produktif di Sumatera Barat secara ekonomi terus mengalami penurunan, meskipun angkanya masih sedikit diatas 50. Meskipun tidak sepenuhnya mendapatkan bonusdemografi, akan tetapi ini merupakan momentum bagi Sumatera Barat untuk meningkatkan kesejahteraan dan menciptakan pertumbuhan ekonomi yang lebih baik.

Yang menjadi permasalahan pokok yang menyebabkan tingginya dependency ratio Sumatera Barat adalah karena tingginya tingkat migrasi keluar penduduk usia kerja. Sehingga perlu upaya dan kebijakan untuk membuat penduduk usia produktif tetap tinggal dan tidak berpindah ke daerah lain. Dengan bercermin pada dua kota di Sumatera Barat yang telah mengalami Bonus Demografi yaitu Padang dan Bukitinggi, perlu upaya untuk melakukan investasi di wilayah lain di Sumatera Barat untuk menggerakkan roda perekonomian yang akan menjadi penarik untuk membuat penduduk usia produktif tetap tinggal.

Salah satu sektor yang menjadi sektor unggulan di Sumatera Barat adalah sektor pertanian. Sumatera Barat merupakan provinsi yang struktur perekonomiannya banyak ditopang oleh sektor pertanian. Iklim dan kondisi wilayah sumatera barat sangat mendukung kegiatan pertanian, sehingga sektor ini tidak hanya dapat memenuhi kebutuhan pangan dan industri di daerah tersebut tapi juga mampu mendukung kebutuhan daerah lain. Sehingga bukan hal yang mengherankan jika Sumatera Barat mampu menjadi salah satu produsen utama komoditi pertanian di Pulau Sumatera terutama sayur-sayuran dan buah-buahan. Pembangunan sektor pertanian akan menciptakan pertumbuhan ekonomi yang lebih baik yang pada akhirnya menciptakan kesejahteraan yang lebih baik bagi masyarakat Sumatera Barat. 
Selain itu Tingkat Keuntungan Komperatif sektor dan subsektor suatu daerah dapat dilihat dari Indek Koefisien Lokasi (Location Quotient). RPJMD Provinsi Sumatera Barat tahun 2010-2015 menunjukkan bahwa sektor pertanian Sumatera Barat memiliki LQ yang lebih besar dari satu yaitu 1,75 yang menunjukkan bahwa sektor ini memiliki keuntungan komparatif yang lebih tinggi dibandingkan dengan sektor yang sama secara rata-rata pada provinsi lainnya di Indonesia. Nilai ini jelas memperlihatkan bahwa sektor pertanian merupakan potensi ekonomi wilayah yang penting bagi pembangunan daerah Sumatera Barat. Bonus demografi merupakan sebuah kesempatan bagi Sumatera Barat untuk menciptakan kondisi perekonomian daerah yang lebih baik. Dengan banyaknya jumlah penduduk usia produktif, berarti tersedianya sumber daya tenaga kerja produktif yang cukup melimpah. Hal ini merupakan sebuah modal bagi Sumatera Barat untuk dapat mengoptimalkan pembangunan sektor pertanian.

Perubahan lingkungan strategis global seperti diberlakukannya Masyarakat Ekonomi Asean pada akhir tahun 2015, juga merupakan salah satu hal yang dadapat dimanfaatkan Sumatera Barat. Dengan diberlakukannya Masyarakat Ekonomi Asian akan membuka kesempatan bagi Sumatera Barat untuk menjalin kerjasama di bidang perdagangan maupun ketenagakerjaan dengan negara tetangga. Bahkan Sumatera Barat memiliki keuntungan terkait posisinya yang berada di pesisir sumatera yang berbatasan langsung dengan Samudra Indonesia. Sumatera Barat memiliki jarak yang cukup dekat dengan beberapa negara Asian lain seperti Malaysia dan Singapura. Hal ini merupakan sebuah peluang yang besar bagi Sumatera Barat dalam memperluas pemasaran komoditi pertanian. Bonus demografi menjadi hal yang sangat menguntungkan karena menyediakan sumberdaya manusia produktif yang banyak yang merupakan hal yang penting dalam mengoptimalkan pembangunan sektor pertanian di Sumatera Barat.

Kajian ini bertujuan untuk menganalisis peluang bonus demografi di Sumatera Barat dan manfaat yang diberikannya untuk dapat mengoptimalkan pembangunan sektor pertanian untuk mendorong pembangunan ekonomi dan wilayah Sumatera Barat. Selain itu itu, tulisan ini juga membahas tentang langkah dan strategi yang dapat dilakukan untuk mengoptimalkan manfaat bonus demografi dalam pembangunan pertanian di Sumatera Barat.

\section{METODE PENELITIAN}

Kajian ini menggunakan studi literatur dengan metode analisa deskriptifkualitatif dengan berbasiskan kajian kepustakaan (library research). Analisa deskriptif kualitatif merupakan suatu metode analisa dengan melakukan pemetaan masalah yang terdapat dalam variable atau kasus yang sedang dikaji lalu kemudian dicari titik korelasinya. Tujuan dari penelitian ini adalah 
mengungkap fakta, keadaan, fenomena, variabel dan keadaan yang terjadi saat penelitian berjalan dan menyuguhkan apa adanya. Penelitian deskriptif kualitatif menafsirkan dan menuturkan data yang bersangkutan dengan situasi yang sedang terjadi, sikap serta pandangan yang terjadi di dalam masyarakat, pertentangan dua atau lebih keadaan, hubungan antar variabel, perbedaan antar fakta, pengaruh terhadap suatu kondisi, dan lain-lain. Sedangkan studi kepustakaan merupakan instrument penelitian dengan mengumpulkan berbagai macam literatur baik dalam bentuk jurnal, buku, prosiding, working paper, maupun sumber data lainnya yang memiliki keterkaitan dengan permasalahan dalam kajian ini. berikut:

Adapun tahapan yang dilakukan dalam analisa kajian ini adalah sebagai

1. Studi pendahuluan dengan melakukan kajian-kajian penelitian terdahulu yang terkait dengan pertanian, pembangunan pertanian di Sumatera Barat dan bonus demografi di Indonesia dan Sumatera Barat.

2. Mengumpulkan literatur yang relavan dengan fokus permasalahan yang diangkat sebagai tema utama dalam kajian ini.

3. Menganalisis sumber literatur yang telah dikumpulkan untuk mendapatkan pemahaman mendasar mengenai korelasi antar studi dan variable yang diteliti

4. Menulis hasil kajian berdasarkan argumentasi analisis berdasarkan data dan kajian literatur yang telah dikumpulkan.

5. Merumuskan rekomendasi berdasarkan argumentasi analisis dari berbagai data dan kajian literature.

\section{PEMBAHASAN}

\section{Bonus Demografi}

Bonus Demografi merupakan salah satu perubahan dinamika demografi yang terjadi karena adanya perubahan struktur penduduk menurut umur.Fenomena transisi demografi ini terjadi karena karena berkurangnya angka kelahiran yang dibarengi oleh tingginya angka kematian dalam jangka panjang.Pada saat terjadi penurunan angka kelahiran dalam jangka panjang, akan berdampak pada pengurangan jumlah penduduk berusia muda $(<15$ tahun), akan tetapi di satu sisi jumlah penduduk usia produktif (15 - 64 tahun) akan meningkat secara drastis sebagai akibat angka kelahiran yang tinggi di masa lalu.Disisi lain jumlah penduduk dengan umur di atas 64 tahunakan meningkat secara perlahan dan kemudian meningkat cepat akibat terjadinya peningkatan usia harapan hidup. Pada saat jumlah penduduk usia produktif jauh melebihi jumlah penduduk usia nonproduktif (kurang dari 15 tahun dan 
diatas 64 tahun) ini lah yang disebut dengan kondisi Bonus Demografi (Rusli, Toersilaningsih, Meirida, Kurniawan, \& Setiawan, 2015)

Parameter yang digunakan dalam menilai fenomena Bonus Demografi adalah Dependency Ratioatau Rasio Ketergantungan, yaitu merupakan rasio yang menggambarkan perbandingan antara jumlah penduduk usia nonproduktif (kurang dari 15 tahun dan diatas 64 tahun) dan penduduk usia produktif (15 64 tahun). Angka Rasio Ketergantungan ini menunjukkan beban tanggungan penduduk usia produktif terhadap penduduk usia non produktif. Pada saat angka rasio ketergantungan rendah, kondisi ini memperlihatkan bahwa penduduk usia produktif hanya menanggung sedikit penduduk usia nonproduktif.

Angka rasio ketergantungan yang rendah akan berimplikasi pada perekonomian negara yang dapat dijadikan sebagai sebuah kesempatan untuk meningkatkan produktifitas sebuah negara. Kondisi ini dapat menjadi sumber pertumbuhan ekonomi melalui pemanfaatan sumber daya manusia yang produktif yang akan mampu menghasilkan pendapatanuntuk memenuhi kebutuhan konsumsi dan meningkatkan tabungan mereka yang pada akhirnya dapat dimobilisasi menjadi investasi (Maryati, 2015). Jadi teori Bonus Demografi pada dasarnya merupakan sebuah teori yang menghubungkan antara dinamika kependudukan dengan ekonomi. Semakin sedikit jumlah usia nonproduktif yang harus ditanggung oleh penduduk usia produktif akan berdampak pada pertumbuhan ekonomi yang lebih baik. Idealnya pertumbuhan ekonomi secara maksimalakan terjadi pada saat Rasio Ketergantungan berada di bawah angka 50.Kondisi ini juga disebut sebagai the window of opportunity (jendela kesempatan) ((KOMINFO, 2015)).

Adioetomo (2005) menyatakan bahwa perubahan dinamika demografi dimana tingginya pertumbuhan penduduk usia kerja akan mempengaruhi Gross Domestic Product per kapita sebuah negara yang juga akan berdampak terhadap:

1. Jumlah penduduk usia kerja yang yang tinggi dan dapat diserap oleh pasar kerja akan meningkatkan total output

2. Akan meningkatkan tabungan masyarakat

3. Tersedianya sumber daya manusia dalam proses pembangunan ekonomi

Kondisi ini hanya akan terjadi sehingga bonus demografi betul-betul dapat dimanfaatkan jika sebuah negara memenuhi beberapa prasyarat, yaitu:

1. Pertambahan penduduk usia kerja dibarengi oleh peningkatan kualitas sumber daya manusia baik dari segi kesehatan maupun pendidikan dan keterampilan serta serta peningkatan soft skill sehingga mereka memiliki daya saing secara global.

2. Penduduk usia kerja dapat diserap oleh pasar kerja yang tersedia 
3. Tersedianya cukup lapangan kerja yang dapat menyerap tenaga kerja yang tersedia

Jika prasyarat di atas tidak dapat terpenuhi yang akan terjadi adalah kebalikan dari bonus demografi (Demographic Dividend) yaitu beban demografi (Demographic Burden). Dimana banyaknya jumlah penduduk produktif yang tidak dapat terserapoleh pasar kerja akan menjadi beban ekonomi sebuah Negara. Pada kondisi ini tingkat pengangguran akan tinggi, sehingga penduduk usia kerja yang tidak memiliki pekerjaan akan menjadi beban bagi penduduk yang bekerja.

Setiap negara hanya akan merasakan satu kali bonus demografi yang hanya akan terjadi selama satu atau dua dekade saja. Hal ini disebabkan karena seiring dengan berjalannya waktu, penduduk usia produktif akan bertransformasi menjadi penduduk usia nonproduktif dan jumlahnya akan terus bertambah. Hal ini akan berimplikasi pada rasio beban ketergantungan yang akan meningkat dengan cepat. Beberapa Negara di dunia telah mampu memaksimalkan bonus demografi yang mereka miliki sehingga saat ini mereka muncul sebagai kekuatan ekonomi baru di dunia seperti Korea Selatan, Taiwan dan Singapura.

Semenjak tahun 2012, Indonesia juga telah memasuki masa bonus demografi.Transisi demografi ini terindikasi dari hasil sensus penduduk tahun 2000 yang menunjukkan fakta signifikan tentang keberhasilan program KB (Keluarga Berencana) yang dilaksanakan dimasa lalu. Fakta yang Nampak dari Sensus Penduduk 2010 memperlihatkan bahwa penduduk berusia dibawah 15 tahun hampir tidak bertambah; dimana pada periode tahun 1970-1980an jumlahnyasekitar 60 juta dan hingga akhir tahun 2000 penduduk dalam kelompok usia ini hanyameningkat menjadi 63-65 juta jiwa. Sebaliknya, penduduk usia 15 - 64 tahun pada tahun 1970 jumlahnya mencapai 63- 65 juta dan telah berkembang menjadi lebih dari 133 - 135 juta, atau mengalami kenaikan dua kali lipat selama 30 tahun (Maryati, 2015).

Selanjutnya maryati (2015) memaparkan, jika dilihat dari ratio dependency, tampak bahwa tingkat ketergantungan penduduk Indonesia memperlihatkan trend yang menurun, dimana pada tahun 1970an nilai dependency ratio Indonesia berkisar antara 85-90 per 100 danpada tahun 2000 menurun hingga ke level 5455 per 100. Hasil sensus penduduk tahun 2010 juga memperlihatkan proporsi penduduk usia produktif yang besar dimana mencapai 66 persendari total penduduk Indonesia. Sedangkan jumlahpenduduk usia muda (15-24 tahun) hanya 26,8 persen atau 64 juta jiwa. Besarnya jumlah penduduk usia produktif tersebut menyebabkan semakin kecilnyanilai angka ketergantungan menjadi 51.Hal ini berarti 100 penduduk usia produktif menanggung 51 orang penduduk takproduktif. Menurut United Nations transisidemografi yang terjadi pada beberapadekade terakhir di Indonesia akanmembuka peluang bagi Indonesia 
untukmenikmati bonus demografi (demographic devident) pada periode tahun 2020-2030.

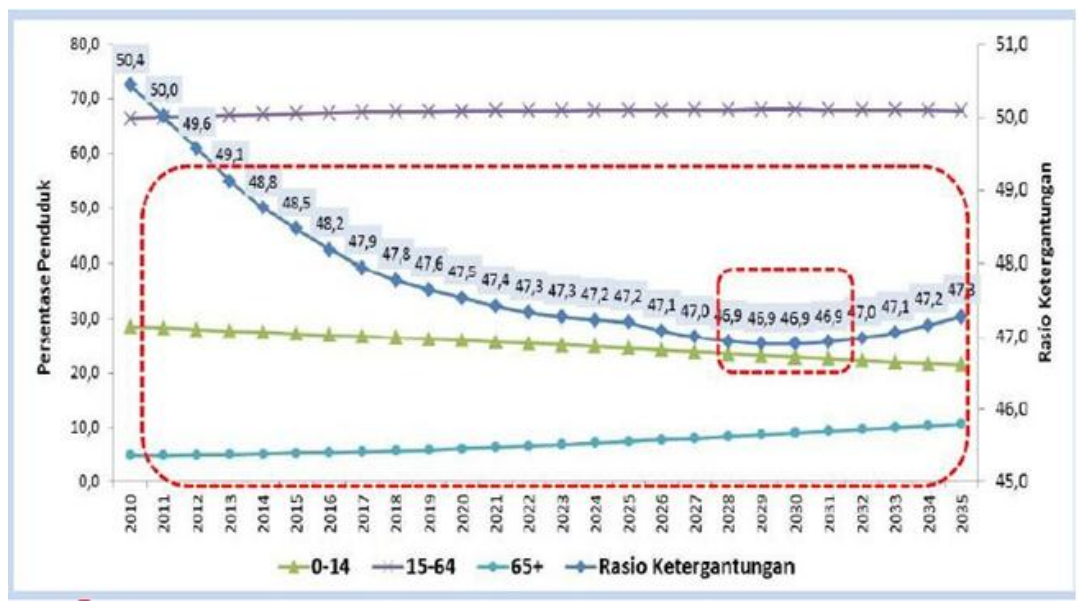

Sumber: Adioetomo (2005)

\section{Gambar 1.}

\section{Transisi Demografi dan Rasio Beban Ketergantungan Indonesia}

Berdasarkan hasil Sensus Penduduk (SP) 2010, penduduk Provinsi Sumatera Barat tercatat sebanyak 4.846 .909 jiwa dengan tingkat Laju Pertumbuhan Penduduk sebesar 1,34 persen yang terdiri dari 2.404.377 laki-laki dan 2.442.532 perempuan, dengan sex rasio sebesar 94,44 persen. Sementara proyeksi yang dilakukan oleh BAPPENAS, BPS dan UNFPA memperlihatkan penambahan jumlah penduduk Sumatera Barat dari tahun 2010 sampai tahun 2035. Dari data tersebut diproyeksikan bahwa pertumbuhan penduduk Sumatera Barat menunjukkan laju pertumbuhan yang cendrung menurun sampai tahun 2035. Pada tahun 2010 jumlah penduduk Sumatera Barat sebesar $4.863,3$ jiwa dan pada tahun 2035 jumlah tersebut diproyeksikan akan mencapai 6.130,4 jiwa. Jika dilihat dari laju pertumbuhan, laju pertumbuhan penduduk Sumatera Barat dari tahun ketahun diproyeksikan akan cendrung terus menurun sampai tahun 2035. Jika pada tahun 2010 laju pertumbuhan penduduk mencapai 1,34 persen, angka ini akan sedikit menurun pada 2015 yaitu 1,33 persen. Angka laju pertumbuhan penduduk ini akan terus menurun menjadi 1,14 persen di tahun 2020 dan akan mencapai angka 0,54 persen pada tahun 2035. 
Table 1. Proyeksi Penduduk Sumatera Barat tahun 2010-2035

\begin{tabular}{lrrrrrr}
\hline \multicolumn{1}{c}{ Parameter } & 2010 & \multicolumn{1}{c}{2015} & 2025 & 2025 & 2030 & 2035 \\
\hline Penduduk & & & & & & \\
Laki - laki & 2409.2 & 2854.2 & 2441.6 & 2874.4 & 2981.1 & 3062.6 \\
Perempuan & 2456.1 & 2612.1 & 2757.2 & 2883.3 & 2987.2 & 3067.8 \\
Total & 4865.3 & 5196.3 & 5498.8 & 5757.8 & 5968.3 & 6130.4 \\
Laju Pertumbuhan & 1.34 & 1.33 & 1.14 & 0.92 & 0.72 & 0.54 \\
Komposisi Umur & & & & & & \\
0 - 14 & 31.1 & 30.3 & 29.2 & 27.5 & 25.7 & 24.2 \\
15-64 & 63.4 & 64.2 & 64.6 & 65.1 & 65.9 & 66.4 \\
65 + & 5.5 & 5.5 & 6.2 & 7.4 & 8.4 & 9.4 \\
Rasio Ketergantungan (\%) & 57.7 & 55.6 & 54.8 & 53.6 & 51.7 & 50.6 \\
Fertilitas/Fertility & & & & & & \\
TFR & 3.02 & 2.83 & 2.65 & 2.46 & 2.3 & 2.15 \\
GRR & 1.5 & 1.4 & 1.3 & 1.2 & 1.1 & 1 \\
NRR & 1.4 & 1.3 & 1.2 & 1.2 & 1.1 & 1 \\
CBR & 23.6 & 21.6 & 19.8 & 18.1 & 16.9 & 15.9 \\
Jumlah Kelahiran & 114.8 & 112.1 & 108.7 & 104.1 & 100.7 & 97.6 \\
Mortalitas/Mortality & & & & & & \\
e0 Laki - laki/Male & 65.7 & 66.7 & 67.6 & 68.2 & 68.5 & 68.8 \\
e0 Perempuan/Female & 69.6 & 70.6 & 71.5 & 72.0 & 72.4 & 72.7 \\
e0 L+P/M+F & 67.6 & 68.6 & 69.5 & 70.1 & 70.4 & 70.7 \\
IMR Laki - laki & 40.5 & 35.9 & 32.2 & 29.9 & 28.6 & 27.6 \\
IMR Perempuan & 28.5 & 25.9 & 23.6 & 22.1 & 21.3 & 20.7 \\
IMR L + P & 34.9 & 31.0 & 28.0 & 26.1 & 25.0 & 24.2 \\
CDR & 8.1 & 7.6 & 7.5 & 7.8 & 8.3 & 9.0 \\
Jumlah Kematian & 39.4 & 39.4 & 41.1 & 44.6 & 49.5 & 55.2 \\
Migrasi/Migration & & & & & & \\
Tingkat Migrasi Netto & -1.6 & -1.8 & -2.0 & -2.2 & -2.3 & -2.3 \\
\hline
\end{tabular}

Berdasarkan proyeksi penduduk menurut struktur umur, jumlah penduduk usia produktif Sumatera Barat masih belum lebih besar jika dibandingkan dengan penduduk usia nonproduktif. Hal ini dapat dilihat dari bentuk piramida penduduk yang cendrung masih mengerucut ke atas. Akan tetapi pada periode 2030 dan 2035, piramida mulai memperlihatkan kecendrungan untuk mengembang di bagian tengah meskipun tidak begitu besar. Hal ini mengindikasikan bahwa diprediksikan pada periode tersebut jumlah penduduk usia produktif mulai meningkat sehingga angka dependency ratio makin kecil. Meskipun belum sepenuhnya akan mendapatkan bonus demografi, ini memberikan peluang bagi Sumatera Barat untuk untuk menciptakan pertumbuhan ekonomi yang lebih baik. Sumatera Barat perlu merumuskan langkah-langkah yang tepat untuk meningkatkan kualitas sumber daya manusia terutama di bidang pendidikan dan kesehatan. Disamping itu, perlu adanya percepatan di sisi ketenagakerjaan berupa penciptaan lapangan 
kerja diberbagai sektor. Mengingat tingginya tingkat migrasi keluar oleh penduduk usia produktif, Sumatera Barat perlu untuk meningkatkan investasi yang akan menciptakan lapangan kerja yang lebih banyak sehingga penduduk usia produktif Sumatera Barat tetap tinggal dalam memajukan Sumatera Barat.

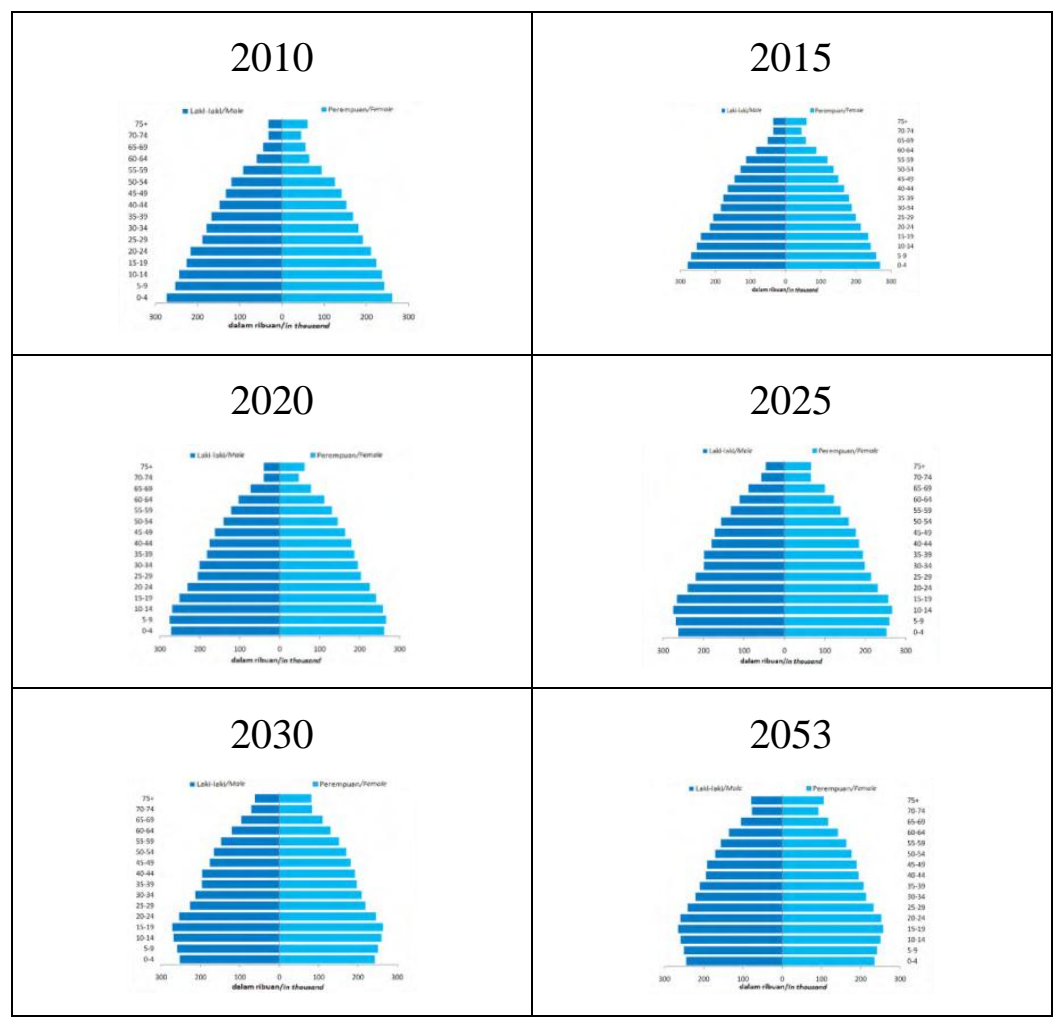

Gambar 2.

Proyeksi Piramida Penduduk Sumatera Barat 2010-2035

\section{Pembangunan Pertanian Di Sumatera Barat}

Sumatera Barat merupakan salah satu provinsi yang kaya akan sumber daya alam dan keanekaragaman hayati yang membuat sektor pertanian menjadi sektor unggulan yang menjadi salah satu penopang utama perekonomian daerah ini. Kekayaan alam dan kondisi alam serta iklim yang menunjang membuat Sumatera Barat menjadi salah satu produsen utama komoditi pertanian di Pulau Sumatera dan dapat memasok kebutuhan konsumsi provinsi lain, sehingga Sumatera Barat dapat dikategorikan sebagai sebagai daerah hinterland.

Sumatera Barat memiliki keunggulan komperatif di sektor pertanian. Hal ini nampak dari nilai indeks koefisien lokasi (Location Quotient, LQ) sektor pertanian Sumatera Barat yang memiliki nilai lebih dari satu yaitu 1,75 yang 
berarti sektor ini mempunyai keuntungan komperatif yang cukup tinggi jika dibandingkan dengan sektor yang sama secara rata-rata pada provinsi lainnya di Indonesia. Di dalam sektor pertanian tersebut terlihat pula bahwa subsetor tanaman pangan ternyata merupakan potensi ekonomi utama Provinsi Sumatera Barat, hal ini terlihat dari nilai LQ sub sektor ini yang cukup tinggi yaitu 1,78.

Sumatera Barat adalah merupakan salah satu provinsi penyangga beras nasional di wilayah Sumatera. produksi padi sumatera barat terus mengalami peningkatan dari 1.889 .489 ton tahun 2006 menjadi 2.211.248 ton pada tahun 2010, atau rata-rata laju pertumbuhan sebesar 4,03persen. Peningkatan produksi jagung juga cukup pesat, dengan rata-rata laju pertumbuhan mencapai 17,63 persen pertahun yaitu dari 202.298 ton tahun 2006 menjadi 354.262 ton tahun 2010.

Komoditas pertanian lain juga mengalami pertumbuhan produksi dari tahun ke tahun. Peningkatan produksi komoditas penting lainnya selama periode 2006-2010: Cabe sebesar 9,87 persen, Kubis 2,89 persen, Tomat 22,91 persen, Jeruk 0,67 persen, Pisang 27,99 persen, dan Markisah 6,50 persen.

Pembangunan pertanian telah memberikan sumbangan dalam pembangunan daerah Propinsi Sumatera Barat baik yang nampak dari pertumbuhan PDRB, penyerapan tenaga kerja, peningkatan pendapatan masyarakat dan penyediaan pangan. Dari sisi permintaan tenaga kerja di Sumatera Barat, sektor pertanian merupakan sektor yang paling banyak menyerap tenaga kerja. Pada tahun 2014 sektor ini menyerap 22,2 persen tenaga kerja, diikuti oleh sektor perdagangan, hotel, restoran yang menyerap tenaga kerja sebesar 19 persen dan kemudian sektor jasa yang menyerap 16,4 persen tenaga kerja.

Pembangunan pertanian ini merupakan hasil kerja keras dan kerjasama yang baik dan terus menerus dari para pelaku pembangunan pertanian, yaitu petani, penyuluh, pelaku usaha di bidang pertanian bersama dengan Pemerintah Pusat dan Daerah (Provinsi dan Kabupaten/Kota.

Berbagai program dan kegiatan terus dilakukan untuk meningkatkan produksi pertanian di Sumatera Barat diantaranya adalah :

1. Memantapkan pengembangan kawasan sentra produksi

2. Memfasilitasi berkembangnya usaha agribisnis komoditi unggulan

3. Mengembangkan sistem dan industri perbenihan

4. Penguasaan dan penerapan teknologi spesifik lokasi dan ramah lingkungan

5. Pembinaan/Penerapan GAP, SOP, GHP/GMP dan lain- lain.

6. Pengembangan pembibitan buah-buahan untuk pengembangan buahbuahan dipekarangan rumah petani.

7. Memperkuat kelembagaan usaha dan kemitraan agribisnis

8. Memfasilitasi pemasaran produk melalui penyediaan informasi pasar 
Pembangunan sektor pertanian yang merupakan bagian dari pembangunan nasional merupakan pembangunan berkelanjutan dan berwawasan lingkungan dengan tujuan untuk meningkatkan produksi baik kuantitas maupun kualitas, mengembangkan usaha profesional yang efektif dan efisien serta mampu bersaing di pasar bebas dapat berkontribusi terhadap perekonomian daerah. Revitalisasi pertanian menjadi penting tidak hanya dalam mendorong percepatan pertumbuhan produksi, tetapi juga dalam peningkatan nilai tambah produk lokal dengan pengembangan agroindustri di pedesaan.

\section{Bonus Demografi Dan Optimalisasi Pembangunan Pertanian}

Berdasarkan proyeksi jumlah penduduk, penduduk usia 15 tahun ke atas di Sumatera Barat akan terus bertambah sampai tahun 2035. Jumlah penduduk 15 tahun keatas diperkirakan akan meningkat dari dari 5.196,5 ribu jiwa pada tahun 2015 menjadi 6.130,4 ribu jiwa pada tahun 2035. Peningkatan jumlah penduduk usia produktif ini merupakan modal pembangunan perekonomian Sumatera Barat jika memenuhi syaraat kualitas keterampilan dan intelektual yang dibutuhkan dunia kerja. Hal ini menjadi sangat krusial saat ini, mengingat akan mulai diberlakukannya Masyarakat Ekonomi ASEAN.

Sementara itu, Peningkatan PDRB sumatera Barat memberikan indikasi peningkatan perekonomian wilayah tersebut. Pada tahun 2015 laju pertumbuhan PDRB Sumatera Barat sebesar 5,85 persen. Dengan adanya peningkatan PDRB, seharusnya dapat menyerap lebih banyak tenaga kerja yang tersedia. Pertanian masih merupakan sektor utama peyerap tenaga kerja terbesar di Sumatera Barat. Dimana sektor pertanian menyerap 33,2 persen tenaga kerja di Sumatera Barat. Kondisi tersebut nampak pada grafik berikut yang menggambarkan pekerjaan yang digeluti penduduk usia di atas 15 tahun.

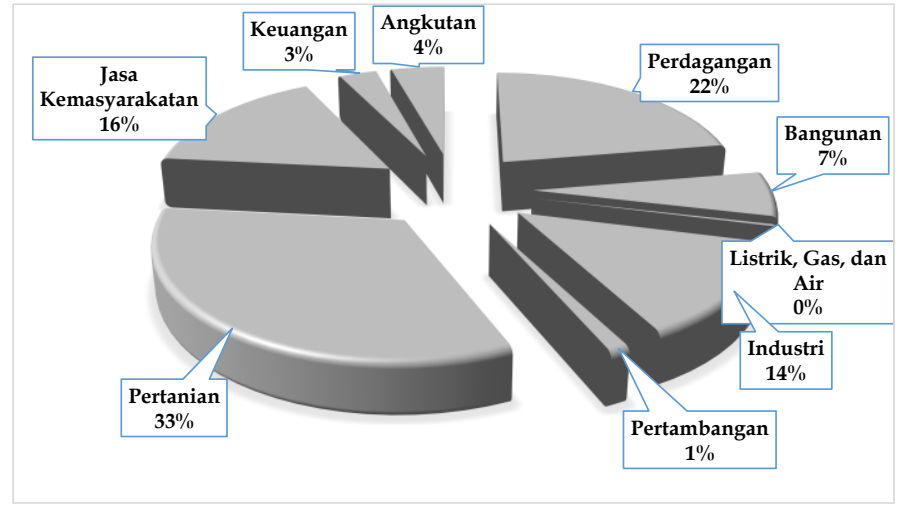

Gambar 3.

Penduduk Umur di atas 15 Tahun yang Bekerja Selama Seminggu yang Lalu Berdasarkan Lapangan Pekerjaan 
Jika dilihat dari tingkat pengangguran terbuka penduduk usia produktif di Sumatera Barat, data memperlihatkan jumlah yang sedikit menurun. Pada tahun 2010 tingkat pengangguran terbuka Sumatera Barat sebesar 6,95 persen dan menurun menjadi 6,18 persen pada tahun 2014. Hal ini mencerminkan bahwa tidak terlalu banyak angkatan kerja yang dapat diserap oleh lapangan kerja. Padahal jika dilihat dari pertumbuhan ekonomi Sumatera Barat yang nampak dari nilai Produk Domestik Regional Bruto, perekonomian Sumatera Barat terus mengalami pertumbuhan. Pada tahun 2011, pertumbuhan PDRB Provinsi Sumatera Barat berdasarkan harga konstan tahun 2000 adalah 6,25 persen dan meningkat menjadi 6,35 persen pada tahun 2012. Dengan membandingkan data nilai PDRB Provinsi Sumatera Barat dengan data tingkat pengangguran terbuka, terlihat bahwa pertumbuhan ekonomi di Provinsi Sumatera Barat belum mampu menyerap banyak tenaga kerja yang tersedia secara maksimal. Kondisi ideal dari pertumbuhan ekonomi terhadap pertumbuhan tenaga kerja adalah ketika pertumbuhan ekonomi mampu mempengaruhi penyerapan tenaga kerja secara lebih besar.

Dari sisi permintaan tenaga kerja di Sumatera Barat, sektor pertanian merupakan sektor yang paling banyak menyerap tenaga kerja. Pada tahun 2014 sektor ini menyerap 33,2 persen tenaga kerja, diikuti oleh sektor perdagangan, hotel dan restoran yang menyerap tenaga kerja sebesar 19 persen dan kemudian sektor jasa yang menyerap 16,4 persen tenaga kerja. Agar tingkat penyerapan tenaga kerja di Sumatera Barat lebih besar dan maksimal, perlu investasi yang lebih besar di sektor-sektor yang pertumbuhannya terus meningkat. Dengan makin banyaknyanya tenaga kerja yang terserap akan maningkatkan pendapatan rumah tangga di Sumatera Barat yang akan memicu konsumsi yang lebih banyak yang pada akhirnya akan mendorong investasi yang lebih tinggi di Sumatera Barat.

Meskipun secara provinsi, Sumatera Barat saat ini belum sepenuhnya mendapatkan bonus demografi, tapi terdapat dua wilayah yang sudah mendapatkan bonus demografi yaitu Kota Padang dengan dependency ratio 42,7 dan Bukittingi dengan dependency ratio 48,2. Selain itu meski angka beban ketergantungan Sumatera Barat masih lebih besar dari 50, tetapi trend dependency ratio sampai tahun 2035 menunjukkan angka beban ketergantungan yang terus menurun. Hal ini mengindikasikan bahwa Sumatera Barat sebenarnya berada diambang window of opportunity yang dapat dimaksimalkan. Berdasarkan proyeksi Badan Pusat Statistik, Sumatera Barat kemungkinan akan dapat menikmati bonus demografi pada periode 2030-2035. Meskipun demikin dependency ratio menunjukkan bahwa jumlah penduduk usia produktif di Sumatera Barat akan terus bertambah dan lebih banyak dari jumlah penduduk usia non-produktif. Semakin sedikit jumlah usia non-produktif yang harus ditanggung oleh penduduk usia produktif akan berdampak pada pertumbuhan ekonomi yang lebih baik.

78 | Yurmarni, Analisis Bonus Demografi Sebagai Kesempatan Dalam Mengoptimal . 
Tingginya pertumbuhan penduduk usia kerja akan mempengaruhi Gross Domestic Product per kapita sebuah negara yang juga akan berdampak terhadap:

1. Jumlah penduduk usia kerja yang yang tinggi dan dapat diserap oleh pasar kerja akan meningkatkan total output

2. Akan meningkatkan tabungan masyarakat

3. Tersedianya sumber daya manusia dalam proses pembangunan ekonomi

Dengan melihat hal ini, Bonus demografi merupakan sebuah momentum bagi Sumatra Barat untuk meningkatkan perekonomian daerah dengan mengoptimalkan pembangunan pada sektor yang menyerap banyak tenaga kerja yang salah satunya adalah sektor pertanian. Mengingat pertumbuhan PDRB sumatera Barat belum maksimal dalam penyerapan tenaga kerja, maka perlu investasi yang lebih besar di sektor-sektor yang pertumbuhannya terus meningkat. Dengan makin banyaknya tenaga kerja yang terserap akan meningkatkan pendapatan rumah tangga di Sumatera Barat yang akan memicu konsumsi yang lebih banyak yang pada akhirnya akan mendorong investasi yang lebih tinggi di Sumatera Barat. Mengingat sektor pertanian merupakan sektor yang paling banyak meyerap tenaga kerja di Sumatera Barat, maka perlu kebijakan di sektor pertanian yang diarahkan untuk pertanian yang lebih maju, ketahanan pangan dan penyerapan tenaga kerja.

Bonus demografi akan menjadi peluang dalam menciptakan kesejahteraan jika dapat memperbaiki dan memperkuat empat prasarat yaitu: a) perbaikan kualitas penduduk, baik pendidikan maupun kesehatan; b) penyediaan lapangan kerja; c) meningkatkan pendapatan keluarga dan d) meningkatkan peran perempuan di pasar kerja. Jika dilihat dari kualitas pendidikan dan kesehatan, Kondisi Sumatera Barat sudah cukup baik yang nampak dari sumatera angka harapan hidup 70,09 tahun (diatas rata-rata nasional), angka melek huruf yang tinggi, rata-rata lama sekolah 9 tahun, semakin menurunnya angka kematian bayi serta cukupnya fasilitas dan tenaga kesehatan.

Kondisi ini akan melahirkan generasi dengan kualitas pendidikan dan kesehatan yang cukup baik. Dengan adanya peningkatan kondisi pendidikan dan kesejahteraan masyarakat akan mendorong peningkatan kemampuan daya beli dan preferensi permintaan masyarakat terhadap komoditas pertanian seperti tanaman pangan dan hortikultura, dalam rangka diversifikasi konsumsi dan peningkatan gizi. Berbagai usaha di bidang pertanian baik pada aspek produksi, pengolahan maupun pemasaran memiliki potensi besar sebagai sumber percepatan pertumbuhan ekonomi daerah. Revitalisasi pertanian menjadi penting tidak hanya dalam mendorong percepatan pertumbuhan produksi, tetapi juga dalam peningkatan nilai tambah produk lokal dengan pengembangan agroindustri di pedesaan.

Disamping itu, mengingat tingginga angka LQ sektor pertanian Sumatera Barat, membuat provinsi ini dikategorikan sebagai daerah hinterland yang dapat 
menopang kebutuhan komoditi pertanian provinsi lain. Bonus Demografi yang akan yang dialami Indonesia dalam periode 2015 - 2035 akan menciptakan pasar yang lebih baik bagi komoditas pertanian Sumatera Barat. Dengan Asumsi terpenuhinya kualitas sumber daya manusia yang baik, penduduk usia produktif yang banyak di Indonesia akan memiliki kemampuan daya beli yang lebih tinggi sehingga akan menciptakan demand yang lebih banyak terhadap produk-produk pertanian yang berkualitas terutama tanaman pangan dan holtikultura. Tidak hanya itu, kondisi ini akan menjadi peluang bagi Sumatera Barat untuk mengoptimalkan upaya pengembangan agroindustri yang menciptakan value added komoditi pertanian. Hal ini tidak hanya akan meningkatkan pendapatan petani di wilayah pedesaan, tapi juga akan menciptakan lebih banyak lapangan kerja yang dapat membantu mengurangi angka pengangguran di Sumatera Barat.

Jika kita melihat dari sisi yang bebeda, pembangunan sektor pertanian menjadi sektor yang sangat penting bagi Sumatera Barat agar dapat mengoptimalkan bonus domografi. Sektor pertanian menjadi sektor penyedia lapangan kerja terbesar yang kinerjanya perlu dioptimalkan agar penduduk usia produktif yang banyak tersebut dapat terserap oleh lapangan kerja. Pembangunan sektor pertanian disamping diarahkan untuk peningkatan produksi, juga seharusnya diarahkan pada upaya untuk menciptakan nilai tambah dari produk-produk pertanian yang akan memacu tumbuhnya usaha agroindustri di pedesaan maupun perkotaan. Agroindustri ini akan menciptakan lapangan kerja yang akan menyerap lebih lebih banyak tenaga kerja. Dengan lebih banyaknya tersedia lapangan kerja, diharapkan akan menampung penduduk usia produktif sehingga bonus demografi tidak akan menjadi beban demografi, tapi bonus demografi yang akan menciptakan kemakmuran dan kesejahteraan bagi Sumatera Barat.

\section{SIMPULAN}

Bonus Demografi merupakan salah satu perubahan dinamika demografi yang terjadi karena adanya perubahan struktur penduduk menurut umur dimana jumlah penduduk usia produktif lebih banyak dari penduduk usia nin produktif. Secara nasional Indonesia sudah memasuki periode bonus demografi sampai tahun 2035. Meskipun tidak sepenuhnya mendapatkan bonus demografi, akan tetapi ini merupakan momentum bagi Sumatera Barat untuk meningkatkan kesejahteraan dan menciptakan pertumbuhan ekonomi yang lebih baik.

Sektor pertanian merupakan sektor yang dapat dioptimalkan oleh Sumatera Barat untuk memanfaatkan periode bonus demografi, karena sektor pertanian merupakan sektor yang memberikan kontribusi terbesar terhadap PDRB daerah dan menyerap banyak tenaga kerja. Disamping itu Sumatera Barat 
merupakan daerah hinterland yang dapat menyokong kebutuhan komoditi pertanian provinsi lain karena nilai LQ nya yang besar $(1,75)$.

Dengan Asumsi terpenuhinya kualitas sumber daya manusia yang baik, penduduk usia produktif yang banyak di Indonesia akan memiliki kemampuan daya beli yang lebih tinggi sehingga akan menciptakan demand yang lebih banyak terhadap produk-produk pertanian yang berkualitas terutama tanaman pangan dan holtikultura. Tidak hanya itu, kondisi ini akan menjadi peluang bagi Sumatera Barat untuk mengoptimalkan upaya pengembangan agroindustri yang menciptakan value added komoditi pertanian. Hal ini tidak hanya akan meningkatkan pendapatan petani di wilayah pedesaan, tapi juga akan menciptakan lebih banyak lapangan kerja yang dapat membantu mengurangi angka pengangguran di Sumatera Barat.

\section{DAFTAR PUSTAKA}

Adioetomo, \& Moertiningsih, S. (2005). Bonus Demografi. Menjelaskan Hubungan Antara Pertumbuhan Penduduk Dengan Pertumbuhan Ekonomi. Pidato Disampaikan pada Upacara Pengukuhan Jabatan Guru Besar Tetap Dalam Bidang Ekonomi Kependudukan pada Fakultas Ekonomi Universitas Indonesia. Jakarta.

BAPPENAS, BPS dan UNFPA. 2013. Proyeksi Penduduk Indonesia 20152035. Jakarta.

BPS, 2015. Keadaan Angkatan Kerja di Indonesia 2015. Jakarta. Biro Pusat Statistik

BPS, 2015. Produk Domestik Regional Bruto Sumatera Barat Menurut Lapangan Usaha. Padang. Biro Pusat Statistik Provinsi Sumatera Barat

BPS. 2015. Survei Sosial Ekonomi Nasional. Jakarta. Biro Pusat Statistik

Djojohadikusumo, s. (1991). Perkembangan Pemikiran Ekonomi. Jakarta: Yayasan Obor Indonesia.

KOMINFO. (2015). Siapa Mau Bonus? Peluang Demografi Indonesia. Jakarta: KOMINFO.

Mardiyah, S. (2001). Konsep Indeks Pembangunan Manusia, Tiga Dimensi Pokok Pembangunan Manusia. Surabaya: Biro Pusat Statistik Propinsi Jawa Timur.

Maryati, S. (2015). Dinamika Pengangguran Terdidik: Tanatangan Menuju Bonus Demografi di Indonesia. Journal of Economic and Economic Education , 3 (2), 124 - 136.

Rusli, S., Toersilaningsih, R., Meirida, D., Kurniawan, U. K., \& Setiawan, K. D. (2015). Potensi dan Implikasi Bonus Demografi di Provinsi 
ISSN: 1412-8837

Banten Tahun 2015-2035. Jakarta: Direktorat Analisis Dampak Kependudukan BKKBN.

Sadono Sukirno, 2006, Ekonomi Pembangunan Proses masalah dan Dasar Kebijakan, cetakan ketiga, Penerbit Kencana, Jakarta

82 | Yurmarni, Analisis Bonus Demografi Sebagai Kesempatan Dalam Mengoptimal . 